\title{
BRIBERY OR JUST DESSERTS? EVIDENCE ON THE INFLUENCE OF CONGRESSIONAL VOTING PATTERNS ON PAC CONTRIBUTIONS FROM EXOGENOUS VARIATION IN THE SEX MIX OF LEGISLATOR OFFSPRING
}

\author{
Dalton Conley \\ Brian J. McCabe \\ Working Paper 13945 \\ http://www.nber.org/papers/w13945 \\ NATIONAL BUREAU OF ECONOMIC RESEARCH \\ 1050 Massachusetts Avenue \\ Cambridge, MA 02138 \\ April 2008
}

This work was supported by funds from the Alan T. Waterman Award of the National Science Foundation. Many thanks to Ebonya Washington for generously sharing her data and insights. Thanks also to the participants at colloquia at U.C. Irvine and Northwestern University. The usual caveats apply. The views expressed herein are those of the author(s) and do not necessarily reflect the views of the National Bureau of Economic Research.

NBER working papers are circulated for discussion and comment purposes. They have not been peerreviewed or been subject to the review by the NBER Board of Directors that accompanies official NBER publications.

(C) 2008 by Dalton Conley and Brian J. McCabe. All rights reserved. Short sections of text, not to exceed two paragraphs, may be quoted without explicit permission provided that full credit, including $\odot$ notice, is given to the source. 
Bribery or Just Desserts? Evidence on the Influence of Congressional Voting Patterns on PAC

Contributions from Exogenous Variation in the Sex Mix of Legislator Offspring

Dalton Conley and Brian J. McCabe

NBER Working Paper No. 13945

April 2008

JEL No. H11,J18,K0

\begin{abstract}
Evidence on the relationship between political contributions and legislators' voting behavior is marred by concerns about endogeneity in the estimation process. Using a legislator's offspring sex mix as an exogenous variable, we employ a two-stage least squares estimation procedure to predict the effect of voting behavior on political contributions. Following previous research, we find that a legislator's proportion daughters has a significant effect on voting behavior for women's issues, as measured by score in the "Congressional Record on Choice" issued by NARAL Pro-Choice America. In the second stage, we make a unique contribution by demonstrating a significant impact of exogenous voting behavior on PAC contributions, lending credibility to the hypothesis that Political Action Committees respond to legislators' voting patterns by "rewarding" political candidates that vote in line with the positions of the PAC, rather than affecting or "bribing" those same votes -- at least in this high profile policy domain.
\end{abstract}

Dalton Conley

Department of Sociology

New York University

295 Lafayette Street, 4th Floor

New York, NY 10012

and NBER

dalton.conley@nyu.edu

Brian J. McCabe

New York University

295 Lafayette Street 4th Floor

New York, NY 10001

bjmcc@nyu.edu 


\section{INTRODUCTION:}

The relationship between Congressional voting behavior and political contributions remains a continuing puzzle for social scientists interested in the American political process. We know that there is a high correlation between how legislators vote and how they are rated by interested Political Action Committees (PACs) on the one hand, and the amount of donations that legislators receive from these lobbyist groups, on the other. Using the data from NARAL Pro-Choice America in this paper, for instance, Table 1 illustrates the high correlation between PAC contributions from NARAL in a given election cycle and voting scores assigned by the organization for the previous Congressional session.

$$
<<\text { Insert Table } 1 \text { here }>>
$$

However, though of critical importance to understanding the role of money in the lawmaking process, sorting out causal directionality here is extremely difficult methodologically. To what extent do contributions from political action committees (PACs) actually influence the voting patterns of elected officials - a particularly worrisome dynamic from the point of view of those concerned with influence peddling? Or, conversely, to what extent do the voting record and ideological commitments of an elected official influence his or her PAC contributions - a "rewards" based system of political patronage that may still be troubling to those concerned with the influence of money on democracy but which is less blatantly a bribery system? 
While most research attempting to disentangle these possibilities has focused on estimating the former dynamic, this paper examines the latter - namely, the extent to which PAC contributions are used as "rewards” for legislators that support PACs position. We focus on PAC donations since such campaign contributions are explicitly linked to a legislative agenda; in the conclusion, we discuss the generalizability of this sector to political donations more generally (i.e. from private individuals, corporations, unions and other donor groups). Concerns about generalizability of PAC money aside, PAC donations are interesting to explore in their own right as they represent a significant share of the total amount of campaign donations received by members of the U.S. Congress. As shown in Figure 1, approximately $40 \%$ of monies received by candidates in recent election cycles for the U.S. House of Representatives comes from Political Action Committees.

$$
<<\text { Insert Figure } 1>>
$$

In absolute terms, the amount of money donated by PACs to successful House candidates has nearly doubled in the last ten years. As Table 2 and Figure 2 illustrate, successful House candidates collected approximately \$300,000 from Political Action Committees in 1998. By 2006, the average amount collected by successful House candidates reached nearly $\$ 550,000$. Similarly, the largest PAC receipts for a single successful House candidate doubled from $\$ 1.2$ million to $\$ 2.4$ million during this period.

$$
<<\text { Insert Table } 2>>
$$




$$
<<\text { Insert Figure } 2>>
$$

While PAC contributions comprise an increasing share of funding in American elections, the proliferation of Political Action Committees has been equally spectacular. According the Federal Election Commission, the number of registered PACs increased five-fold between 1975 and 2000. This growth has been particularly spectacular amongst corporate PACs, which comprise nearly two-fifths of PACs registered with the Federal Election Commission in 1999. Table 3 details the annual growth of Political Action Committees, and Figure 3 charts their astronomical rise by reported sector.

$$
\begin{aligned}
& <<\text { Insert Figure } 3>> \\
& <<\text { Insert Table } 3>>
\end{aligned}
$$

The growth of Political Action Committees occurred contemporaneously with increased concerns amongst the electorate about the role of money in our political system. Anecdotal evidence suggests--and recent public opinion polls confirm--that the pervasiveness of money in the nation's political process is viewed as a serious concern. For instance, a 2000 Fox News/Opinion Dynamics poll found that over 80\% of respondents believed Political Action Committees wielded too much power and influence in Washington. Similarly, over half of adults surveyed in a 2000 Newsweek poll claimed that the influence of political contributions on government policy was a major problem in Washington. 


$$
\begin{aligned}
& <<\text { Insert Table } 4>> \\
& <<\text { Insert Table } 5>>
\end{aligned}
$$

These polls underscore concern amongst the electorate about the influence of money in the policymaking process. Taken together, the growth of Political Action Committees, their prevalence in financing political campaigns, and mounting concern about the influence of money and politics justify the scope of this study.

\section{BACKGROUND:}

Despite the enormity of the scale of political donations and the seriousness of the issue, both from a theoretical perspective as well as from the point of view of public concern about the potential 'tainting' of the political process, determining the direction of causality between political contributions and voting behavior remains elusive. The majority of research on this subject examines the hypothesis that financial contributions from political action committees influence the voting decisions of members of Congress (see Grenzke 1989a; Grenzke 1989b).

One theory, for example, suggests that over and above other important factors such as party affiliation (Stratmann 1996; Rudolph 1999), seniority (Grenzke 1989a), committee assignments (Grier and Munger 1993; Grier and Munger 1991; Evans 1988) and other legislator characteristics, ideological 'fence-sitters' should elicit the greatest financial support in a 'bidding war' of sorts for their swing votes on important issues. In terms of individual legislator characteristics, this theory predicts that moderates, rather than committed liberals or conservatives, are most susceptible to influence peddling from 
PACs. Fleischer (1993) concludes that his results on the impact of defense PACs on defense spending "indicate that contributions from defense PACs can under certain circumstances marginally influence the votes of members, especially those members with weaker ideological predispositions.” (Fleischer 1993: 406) Those without clear, consistent policy positions are viewed as most swayable, and political contributions are aimed at influencing these legislators’ voting behavior.

Yet, other recent empirical evidence suggests the opposite - that a consistent ideological position is associated with high campaign contributions. In a recent NBER working paper, Kroszner and Stratmann (2000) find that a clear, well-known ideological position increases campaign contributions. Using the percent of repeat givers as a proxy for a legislator’s reputational development, Kroszner and Stratmann (2000) report that "high reputational development is rewarded with high total contributions.” (Kroszner and Stratmann 2000: 25) In their analysis, contributions from PACs increase as legislators build their reputational clarity, suggesting that this consistent ideological positioning benefits legislators. Such a result suggests that rather than 'buying' votes directly, political contributors may tend to invest in legislators who will provide 'sure' returns based on prior patterns. ${ }^{1}$

Net of individual legislator characteristics, the literature suggests that PACs should be most influential in low profile, non-ideological issues. Again, Fleisher (1993) tests the effect of political contributions from organizations involved in the national

\footnotetext{
1 These conclusions build on earlier attempts to understand the effect of ideological positioning on campaign contributions. Some research leaves out the ideology variable because of its multicolinearity with political party affiliation (Grenzke 1988). Other research includes an aggregate measure of ideology, such as the Americans for Democratic Action (ADA) score for each legislator, and finds significant effects of ideology on PAC contributions (Evans 1988; Borck 1996).
} 
defense industry. Using a two-stage least squares estimation procedure to overcome the simultaneity of defense PAC donations and voting behavior, Fleisher predicts PAC contributions using characteristics of individual legislators and their districts in his model, including a legislator's campaign receipts from other PACs. In the second stage, this instrumented variable for defense PAC contributions is used to predict support for defense legislation in the $100^{\text {th }}$ Congress. While Fleisher concludes, along with existing literature, that ideology plays a powerful role in explaining voting behavior, he also finds a significant effect of defense PAC contributions, although the magnitude of this effect is small. Unfortunately, the variables Fleisher claims to be exogenous in the first stage (e.g., ideology, contracts received from the Defense Department, party, etc.) in predicting defense PAC contributions do not meet the exclusion restriction; in other words, we should expect all those factors to affect voting on defense issues independent of donations.

Likewise, Grenzke (1989b) finds that political contributions are unlikely to change voting behavior, even for low profile, niche issues. In the first stage, Grenzke predicts PAC contributions from a host of variables, including electoral vulnerability and member’s power (Grenzke 1989b: 8). Grenzke lags the effect of political contributions by using contributions in both the simultaneous year and the preceding year to when the behavior was measured. In other words, for voting during the $95^{\text {th }}$ Congress (19771978), Grenzke uses both contributions during the 1977-1978 election cycle, as well as during the 1975-1976 election cycle. Of twenty-nine models, Grenzke finds only four significant associations in the simultaneous relationship and one significant association in the lagged relationship. As a result, Grenzke concludes that "contributions from 120 
PACs affiliated with 10 large interest groups generally do not maintain or change House members’ voting patterns.” (Grenzke 1989b: 19) As with Fleisher’s study, Grenzke’s instrument (electoral vulnerability) fails the second-stage exclusion restriction, as we would expect that variables like electoral vulnerability to affect both PAC contributions (if more vulnerable incumbents are on the prowl for money) and voting behavior (if electoral vulnerability makes incumbents more likely to vote in ways appealing to particular constituencies that may, for example, stimulate job growth in their districts).

In addition to examining high-visibility and low-visibility issues separately, Grier and Munger (1993) argue that institutional context matters. In the House, where much of the legislative work is performed in committee, committee assignments are significant predictors of campaign contributions; in the Senate, on the other hand, party affiliation plays a more significant role in determining contributions. Witko (2006) builds on this analysis by arguing that the "issue context" matters. Using probit analysis to measure the effect of PAC contributions on ideological, visible issues versus non-ideological, nonvisible issues, he argues that contributions influence voting behavior on non-visible issues, but influence measures of participation on more visible ones. These measures of participation include the number of times a legislator participates in a committee hearing, the number of amendments submitted by legislators, and the number of lines of text added by legislators to hearing transcripts. Thus, Witko challenges the traditional explanation that PAC contributions matter for non-ideological, non-visible issues. He argues instead that, for visible, ideological issues, PAC contributions matter earlier in the legislative process, when legislators are participating in committee hearings and offering legislative amendments. (Witko 2006: 289) This analysis leads to a more nuanced 
understanding of the impact of campaign contributions on political behavior by suggesting that researchers must examine committee participation, as well as actual voting behavior.

While Witko (2006) offers an alternative to the money-votes linkage by suggesting that political contributions are linked with other forms of legislator participation, recent experimental evidence on the relationship between contributions and access suggests otherwise. Chin (2005) conducted an experiment in which Congressional schedulers were given a set of hypothetical schedule requests, along with a weekly schedule for a member of Congress. These staff members are asked to schedule the member of Congress, based on the set of letters and requests available to the scheduler. Using a variety of experimental conditions, Chin (2005) concludes that it is constituency status, rather than campaign contribution history, that significantly affects the likelihood of a scheduling request being accepted. While this experimental study may be of limited external validity due to the hypothetical nature of the research, it does suggest that political contributions may not be paramount in gaining access to legislators.

In another effort to get at the heart of the relationship between voting behavior and political contributions, Bronars and Lott (1997) examine the voting behavior of retiring members of Congress in their final term in Congress. If the need for campaign donations to secure reelection impacts legislative behavior, then the decision to retire and subsequently stop receiving political contributions - should change the voting behavior of members by freeing them from such considerations to instead purely vote their conscience. They find no evidence for this hypothesis, thereby calling into dispute the notion that political contributions affect voting behavior. However, it could be the 
case that PACs have already 'trapped' retiring legislators into a path-dependent voting record that conditions votes during that member's final Congressional term; or that the retiring member is responsive to the same lobbying forces but this time with the carrot of a lucrative position in the private sector post-retirement; or that the member is voting to maximize donations to his/her anointed successor in an implicit bargain.

The evidence presented thus far-both from experimental research examining the relationship between money and access, as well as the quantitative research linking political donations to voting behavior - may allay the fears of those concerned with the 'buying' of votes through campaign donations by political action committees. If the causal relationship between donations and voting is weak, we should expect that the 'residual' impact of voting on donations is strong to account for the high overall correlation. With this expectation in mind, the present study tries to quantify the extent to which voting patterns of a legislator during a given Congress affects the donations of a particular PAC to that member in the subsequent election cycle. Of course, merely deploying temporal ordering does not satisfy the condition of strict (or even weak) exogeneity in a time series analysis. For example, it could be that members of Congress vote a certain way in anticipation of (i.e. fishing for) donations from a PAC (or perhaps as a result of explicit or implicit promises). Clearly, such a dynamic would be troubling from the point of view of the democratic process just as much as simultaneous exchange of money for votes or prior donations driving future votes.

To preempt this issue, we employ a unique estimation strategy: We use exogenous variation in the sex mix of legislators' children to predict their voting patterns on certain issues. Sex mix has been used as an instrument for parental labor force 
participation (Angrist and Evans 1998), for parental divorce ( Dahl and Moretti 2004), and for parental investment in offspring (Conley and Glauber 2006). The appeal of this instrument lies in its random assignment in a country—like the U.S. —-where there is little to no antenatal sex selection (i.e. sex selective abortion).

This utilization of the random variation provided by the sex-mix of offspring to predict voting patterns becomes the first stage in an IV-regression of lagged voting on political contributions, thereby providing us with a 'clean' estimate of the impact of voting on donation. Specifically, we follow Washington (2007) who shows that Congressmen who have more daughters—conditional on number of total children—-tend to vote in a way that receives higher ratings from women's issues PACs, such as the National Organization for/of Women (NOW), and lower ratings from pro-life PACs, like Right to Life. Her results hold for legislators from both parties - though, of course, Democrats receive higher average scores. She interprets this result as a 'socialization effect'-that is, daughters, she argues, influence the thinking of their parents. However, it is equally possible, we believe, that her finding results from a shift in the legislator's own interests. If a legislator does not have a daughter, then s/he may care less about policies to better the lives and opportunities of women than someone who has a daughter, ceritus parabus. Put more starkly, if a legislator does not have a teenage daughter who may become pregnant, s/he may not be as personally impacted by, for example, abortion restrictions. $^{2}$

The good news is that, for our analysis, the reason(s) for the effect are not important as long as they meet the exclusion restriction for our second stage. Namely,

\footnotetext{
${ }^{2}$ In Washington's data, the association between proportion daughters and NOW score is positive for both male and female legislators. However, only for male legislators is the association statistically significant, and the magnitude of the association is greater for men than for women. (See Washington 2007, Table 3)
} 
there can be no indirect effect (i.e. not reflected in their voting record and rating of that record by the PAC) of the sex mix of legislators' offspring on the donations they receive from a given PAC. This boils down to the assumption that PACs do not intentionally or unintentionally give more donations to legislators with daughters, net of their evaluations of those legislators. This seems like a reasonable assumption. If there were subtle bias in PAC behavior thanks to the composition of the legislator's family, we would likely see it in the overall rating of that legislator, too, and not just in the donation amounts. This assumption falls apart to the extent that ratings are made very unalterable algorithms and donations are made by more flexible, 'softer' criteria. Even if this difference in PAC decision making processes exists at these two decision points, it is still unlikely to reflect bias induced by the sex mix of children to any significant degree

Another way that the exclusion restriction might be violated would be if the presence of daughters makes the legislators more or less powerful in Congress in ways that are independent of their actual votes. For example, conditional on how many children a member of Congress has, the proportion of daughters may influence how well liked s/he is in her/his home district; or partisanship ${ }^{3}$; or it may affect committee assignment; or leadership roles; or tenure-all factors that have been shown to be associated with donation levels. While it may be easy to come up with reasons why the number of children a legislator has could affect their Congressional careers in any number of ways, it is much more difficult to suggest that the proportion of daughters

\footnotetext{
${ }^{3}$ In running descriptive statistics for legislators of both parties, we find that the proportion daughters differs by political party, and the difference - in which Republicans have a lower proportion daughters - is significant at the .05 level. The mean proportion daughters for Republicans is 0.49 and for Democrats is 0.53. A t-test for the difference in means suggests that we can reject the null hypothesis at the .05 level. This may suggest that proportion daughters influences party affiliation (though it also may be a chance finding given the number of observables we tested and the small, substantive magnitude of the difference); nonetheless, we control for party ID in our analysis.
} 
does. One possible problem is that having two same sex children among the first two born has been shown to influence whether or not parents go on to have additional children (Angrist and Evans 1998; Conley and Glauber 2006). However, our key indicator is not "same sex" but rather proportion girls; furthermore, the fact that the impact of each additional daughter appears linear and works for legislators with two children or with three, the idea that the presence of two daughters is driving PAC score through fertility should be allayed.

\section{DATA AND METHODS:}

We estimate the effect of voting behavior on contributions from Political Action Committees using a two-stage least squares approach. As previous research finds that the proportion daughters for federal legislators is a significant predictor of voting behavior for women’s issues (Washington 2007), we limit our analysis to issues identified by NARAL Pro-Choice America in the annual “Congressional Record on Choice.” NARAL Pro-Choice America is one of the largest organizations advocating for a woman's right to choose. The organization lobbies on women's issues, including birth control, abortion, and sex education, and has contributed more than two million dollars to political candidates in each of the three previous election cycles. The organization also rates legislators, based on their voting patterns for an aggregate set of bills tracked by the organization.

For the present project, we compiled an extensive dataset for members of the United States House of Representatives from the $105^{\text {th }}$ Congress (1997-1998) through the $108^{\text {th }}$ Congress (2003-2004). Using a dataset originally compiled by Washington (2007) 
that included proportion daughters, age, and religion of each member of the House of Representatives, we expanded the dataset to include PAC contributions from NARAL Pro-Choice America for each election cycle from 1998 to 2006, as well as scores from NARAL Pro-Choice America from 1997 through 2004.

In our sample of legislators, the mean representative is 55 years old and has 2.45 children. Of the 1,740 person-year observations in our dataset, four observations are missing data on the number of children. ${ }^{4}$ Another 225 observations are legislators without children, and these legislators are therefore excluded from our analysis. As a result, we limit our analysis to the 1,511 observations in which legislators have children, and we have accurate data about the sex mix of those children. Of this sample of legislators with children, the mean proportion of daughters is 0.51 .

In the first stage of each analysis (outlined below), we use scores assigned by NARAL as the dependent variable. NARAL scores legislators on a scale of $0-100$ based on a composite of votes each year, and these scores are published in NARAL's annual “Congressional Record on Choice.” A legislator receiving a score of 100 voted in concurrence with the NARAL position on each of the Congressional votes for that year; a legislator receiving a score of 0 voted the opposite of the position supported by NARAL on each piece of legislation. The number of votes used in the annual composite varies by year, with as few as two votes in 2004 to nineteen votes in 1997. In a typical year, the Congressional Record on Choice includes votes on issues like the "Partial Birth" Abortion Ban; an amendment to the Department of Defense Authorization Act forbidding military personnel from obtaining privately-funded abortions at overseas military

\footnotetext{
${ }^{4}$ Data on the sex mix of children is missing for Representatives Michael Pappas (R-NJ), Timothy Johnson (R-IL), and Michael Burgess (R-TX).
} 
hospitals; an amendment to the Agricultural Appropriations banning the Food and Drug Administration (FDA) from testing drugs for early, non-surgical abortions; the denial of U.S. family planning assistance abroad to non-governmental organizations that use private funds to provide abortions; and an amendment to the Labor, Health and Human Services Appropriations banning the prescription of emergency contraception pills at school-based health centers. ${ }^{5}$ We transformed annual scores for legislators into a score for each legislator in each Congress by averaging a legislator's score across the two-year period for that Congress. For example, if a legislator received a score of 80 for the year 1997 and 90 for the year 1998, we averaged that legislator's score to give him/her a NARAL score of 85 for the $105^{\text {th }}$ Congress. In Table 6 , we provide the frequency of scores for legislators in each Congress. As the table suggests, the majority of legislators scored either a 0 or 100 in each Congress, although there is significant variation across the range of scores.

$$
<<\text { Insert Table } 6 \text { here }>>
$$

The mean NARAL score varied significantly by political party, with the average Democrat receiving a NARAL score of 76, while the average Republican received a NARAL score of 11.

Information on political contributions from NARAL Pro-Choice America was compiled from the website www.opensecrets.org, and includes observations for each person-year. In the four election cycles considered in this paper (and, thus, 1,740 personyears), 1,457 observations - or approximately $84 \%$ - received no money from NARAL

\footnotetext{
${ }^{5}$ The examples listed here are each from the 2000 Congressional Record on Choice.
} 
Pro-Choice America. Table 7 illustrates the frequency distribution, by $\$ 1,000$ contributions.

$$
<<\text { Insert Table } 7 \text { here }>>
$$

The maximum donation recorded was $\$ 10,000$, and it appears in thirteen cases in our data. The mean contribution per person-year is $\$ 396.87$, although this varies by political party, as well. The average Democrat received $\$ 765.48$ from NARAL, whereas the mean Republican received \$59.10. In fact, only seven Republican received donations from NARAL Pro-Choice America during the time period covered, accounting for 13 unique observations in our dataset. ${ }^{6}$ Of the observations for Democrats in our dataset, there are 270 cases - or $32.45 \%$ of observations for Democrats - in which members received contributions from NARAL.

We begin by using a "naïve” ordinary least squares analysis to predict whether a legislator was the recipient of donations from NARAL Pro-Choice America. In this model (and all subsequent ones), we have accounted for the fact that a legislator's score is likely to affect political contributions in the subsequent election cycle by lagging our measure of PAC contributions. We match donations in an election cycle with the score received by a legislator during the preceding Congress. For example, we predict PAC donations in the 1998 election cycle using a legislator’s NARAL Pro-Choice America score for the years $1997-1998\left(105^{\text {th }}\right.$ Congress). The temporal ordering of this

\footnotetext{
${ }^{6}$ The following is a list of Republic members receiving NARAL contributions, and the number of election cycles during which they received contributions: Constance Morello (R-MD) - 3; Benjamin Gilman (RNY) - 1; Sherwood Boehlert (R-NY) - 2; Nancy Johnson (R-CT) - 3; Frank Pallone (R-NJ) - 1; Rob Simmons (R-CT) - 2; Steve Israel (R-NY) - 1 .
} 
estimation technique logically suggests that voting behavior in the $105^{\text {th }}$ Congress has an effect on the political contributions received in the campaign for the subsequent $\left(106^{\text {th }}\right)$ Congress. However, the naïve regression assumes that a legislator's score is independent of the likelihood of receiving a contribution from NARAL Pro-Choice America, and is therefore treated as an exogenous independent variable in the regression analysis.

Although the theoretical literature gives us ample reason to dismiss this assumption, the naïve model enables comparison with the instrumented model. In this linear probability model, we control for individual legislator characteristics, including party affiliation, age and religious affiliation. This model is shown as equation one, below. ${ }^{7}$

$$
\begin{aligned}
& Y=\alpha+\beta_{1} A G E+\beta_{2} \text { DEMOCRAT }+\beta_{3} \text { CHRISTIAN }+\beta_{4} \text { CATHOLIC } \\
& +\beta_{5} \text { PROTESTANT }+\beta_{6} \text { NARALSCORE }+\varepsilon
\end{aligned}
$$

where $\mathrm{Y}$ is a dichotomous variable indicating whether or not a legislator received money from NARAL; AGE is the legislator's age; DEMOCRAT is a dummy variable for party affiliation; CHRISTIAN, CATHOLIC, and PROTESTANT are three dummy variables for religion (with a fourth dummy variable, OTHERRELIGION, excluded as the reference category); and NARALSCORE is the legislator's NARAL score as observed. We then compare this approach to results from a 2SLS approach. The first stage predicts NARAL score using the same set of controls, along with a variable, PROPDAUGHT (proportion daughters of total children)

$$
\begin{aligned}
& \text { NARALSCORE }=\alpha+\beta_{1} A G E+\beta_{2} \text { DEMOCRAT }+\beta_{3} \text { CHRISTIAN }+\beta_{4} \text { CATHOLIC } \\
& +\beta_{5} \text { PROTESTANT }+\beta_{6} \text { PROPDAUGHT }+\varepsilon
\end{aligned}
$$

\footnotetext{
${ }^{7}$ A logistic regression model yields similar estimates. We prefer the LPM since Heckman and Macurdy (1985) and others have persuasively argued that in an IV- or 2SLS-regression with a dichotomous Y, a linear probability estimation is most consistent.
} 
Our second stage regression (LPM) estimates the impact of this instrumented NARALSCORE* on the likelihood of receiving a donation from NARAL for each legislator in the subsequent election cycle. This second stage is shown in Equation 3, below:

$$
\begin{aligned}
& Y=\alpha+\beta_{1} A G E+\beta_{2} \text { DEMOCRAT }+\beta_{3} \text { CHRISTIAN }+\beta_{4} \text { CATHOLIC } \\
& +\beta_{5} \text { PROTESTANT }+\beta_{6} \text { NARALSCORE } *+\varepsilon
\end{aligned}
$$

After presenting the main results, we then refer the reader to an appendix, which contains additional analysis, including an IV-regressions broken down by various demographic and political variables in our sample, including sex, region, political party and age in an effort to determine whether there are heterogeneous treatment effects.

\section{RESULTS:}

As a baseline for comparison, first we estimate an Ordinary Least Squares model of the likelihood of NARAL donation in a given election cycle based on NARAL score for the previous Congress_-using only time ordering as a claim on exogeneity. We present the results of our naïve regression in column A of Table 8, below. While we dismiss these results out of hand because of concerns about endogeneity previous discussed, the presentation of the naïve results allow researchers to compare the two stage least squares estimation with the ordinary least squares regression to see how the latter may misrepresent the magnitude of the effect of a legislator's NARAL score on the probability of receiving a PAC donation.

$<<$ Insert Table 8 here $>>$ 
Column B of Table 8 shows the first stage of our instrumental variable approach.

In the first stage of our estimation, we find that proportion daughters has a significant and positive effect on a legislator's NARAL Pro-Choice America score, net of a legislator's age, religion, and political affiliation. As Column B of Table 8 reports, the positive association between proportion of daughters and legislator's NARAL score is significant at the .001 level, and has an association of nearly 10 points. These results are consistent with the hypothesis that the proportion of daughters has an effect on voting behavior, net of other individual characteristics. More precisely, an increase in the proportion of daughters makes a legislator more likely to support legislation important to NARAL ProChoice America such that going from no daughters and all sons to all daughters and no sons would raise a legislator's NARAL score by 10 points.

In column $\mathrm{C}$ of Table 8, above, we show the second stage results in which we use a linear probability model and the instrumented value of NARAL score (from the first stage shown in Column B) to predict the likelihood that a legislator received contributions from NARAL Pro-Choice America. As shown in Column C, we find that our instrument for NARAL score is highly significant, and, in fact, the parameter estimate is larger than the naïve OLS estimate, though a test shows that they are not significantly different from each other. ${ }^{8}$

\footnotetext{
${ }^{8}$ To extend our analysis, we also estimated a second stage modeling the effect of a legislator's instrumented score on the amount received, conditional on receiving any contribution from NARAL. (Table not shown; available from authors upon request.) We find that, conditional on having received money from NARAL, the relationship between NARAL score and PAC contributions is not significant. However, we suspect that the small sample size resulting from sub-setting our data is driving the nonsignificant results. Given the problematic nature of the small sample size $(n=231)$, we also ran a two-stage least squares estimate of the effect of NARAL scores on amount of NARAL contributions for the entire population of legislators (i.e. including zero values, $n=1511$ ). When we include the entire population, rather than a subset of the population, we find that a legislator's NARAL score does, in fact, have an effect on his/her PAC donations. A one-point increase in a legislators NARAL score is associated with an increase of \$20 in PAC contributions from NARAL. However, this model is of limited additional value to
} 


\section{DISCUSSION \& CONCLUSIONS:}

The relationship between voting behavior and political contributions remains a central puzzle in the American political system. Research attempting to disentangle the effects of money in the political process has pointed the causal arrow from contributions to behavior, asking whether contributions from political action committees affects the voting patterns of legislators. While this literature is inconclusive, much of the evidence suggests that the high correlation between voting behavior and campaign contributions does not result from an attempt by PACs to 'buy' votes.

In this paper, we explore an alternative perspective on money and politics. Flipping the causal arrow, we ask whether voting behavior determines political contributions and, if so, what is the strength of that relationship. The evidence presented in this paper lends credibility to the hypothesis that a legislator's voting behavior affects contributions received from political action committees in subsequent election cycles. Using exogenous variation in the sex mix of a legislator's children, we employ a two stage least squares estimation procedure to measure the impact of voting behavior on political donations. We find that the proportion daughters has a significant effect on a legislator's voting behavior with regard to women's issues, as measured by NARAL ProChoice America scores compiled in their “Congressional Record of Choice.” In the second stage of our analysis, we find a positive association between NARAL score and the likelihood of a NARAL PAC contribution, suggesting that voting behavior largely determines political contributions. When we compare this estimate using exogenous 
variration in voting patterns to the "naïve" estimate that merely deploys observed voting score in a OLS linear probability model, we find that the two parameter estimates are not significantly different, suggesting that the observed relationship is one of rewards and not bribery - at least for this PAC on this issue. A comparison of the results from the two models is shown in Figure 4, below

\section{$<<$ Figure 4 about Here $>>$}

While our evidence moves away from a 'vote buying' hypothesis towards a system of 'rewards', we are careful in extrapolating our results beyond the particular policy domain identified in this analysis. Reproductive rights represent a unique, ideologically-charged policy domain, and the ex ante commitment of legislators to particular political positions is, we suspect, quite strong. The 'rewards' system identified here might be particularly strong for ideologically charged issues where the possibility of position shifting from 'vote buying' is improbable. In low-visibility, low-impact issues, the possibility of a 'vote buying' system may be more plausible, and could be empirically tested through a similar estimation procedure. We encourage researchers to take advantage of the methodologies introduced here to test whether the 'rewards' system holds for less ideological issues - if, of course, suitable instrument for such voting patterns can be found.

On the other hand, it is possible that the unusually high-visibility of reproductiverelated issues might force choice-related PACs to be more conservative in dolling out rewards, given the increased scrutiny they endure. Regardless of the direction of the causal arrow, if public perception of high visibility issues suggests that Political Action 
Committees are using money to 'buy votes,' then Political Action Committees might respond to this increased public scrutiny by tempering their contributions. In this scenario, PACs advocating for ideological, high-visibility issues may be rewarding legislators less than those engaged in low-visibility issues. Not needing to respond to public scrutiny, low-visibility PACs may, in fact, be the most engaged in this system of rewards.

Our analysis is not intended to suggest that Political Action Committees do not influence the behavior of legislators. There are, of course, other ways in which Political Action Committees sway individual legislators’ voting behavior. They may apply pressure in committees, or use their prowess to affect the content of legislation. Our analysis speaks only to the direct impact of political contributions from Political Action Committees to legislators, not to a host of alternative mechanisms through which Political Action Committees exercise their political clout. Instead, it attempts to unravel the age-old political question about the relationship between political contributions and voting behavior. The analysis is similarly limited in disentangling the relationship between voting behavior and other sources of political contributions, like individual donors, labor unions, or corporations. Political Action Committees are unique insofar as they attempt to influence policy on a particular, well-defined subset of political issues (e.g., women's issues). The relationship between individual contributions, corporate contributions or those made by labor unions may be more difficult to disentangle, as the measurable outcomes are not as straightforward as those presented in this analysis. Nonetheless, future analysis should look towards exploring the important relationship between voting behavior and individual donors, corporate contributions and labor unions. 
Despite these limitation, the current paper offers some comfort to careful political observers that ours may not be, after all, a system of bribery—at least for issues of major public concern. Instead, it’s just desserts. 


\section{APPENDIX}

While the pooled data provides evidence of the exogenous impact of voting behavior on political contributions, we further disaggregate the data by examining particular sub-samples of our population. In Table A1, we run similar models by various demographic groups, attempting to determine whether the relationship between scores and money vary by subgroup. These results suggest that the relationship between money and scores, as outlined above, is particular strong for Democrats and legislators older than 55 years old, the mean age in our dataset. A one-point increase in a legislator's instrumented score is associated with a $1.3 \%$ increase in the likelihood of receiving contributions for legislators over 55 years old. Likewise, we find that an increase in instrumented NARAL score is associated with approximately a one-percentage point increase in the likelihood of receiving donations for both Democratic legislators and nonSouthern legislators.

\footnotetext{
$<<$ Insert Table A1 Here $>>$
} 


\section{REFERENCES:}

Angrist, Joshua D. and William N. Evans. 1998. Children and Their Parents' Labor Supply: Evidence from Exogenous Variation in Family Size. The American Economic Review 88(3): 450-477.

Borck, Rainald. 1996. Ideology and interest groups. Public Choice 88: 147-160.

Bronars, Stephen G. and John R. Lott, Jr. 1997. Do Campaign Donations Alter How a Politician Votes? Or, Do Donors Support Candidates Who Value the Same Things That They Do? Journal of Law and Economics 40: 317-350.

Chappell, Jr., Henry W. 1982. Campaign Contributions and Congressional Voting: A Simultaneous Probit-Tobit Model. The Review of Economics and Statistics 64(1): 77-83.

Chin, Michelle L. 2005. Constituents versus Fat Cats: Testing Assumptions about Congressional Access Decisions. American Politics Research 33(6): 751-786.

Conley, Dalton and Rebecca Glauber. 2006. Parental Educational Investment and Children's Academic Risk: Estimates of the Impact of Sibship Size and Birth Order from Exogenous Variation in Fertility. Journal of Human Resources.

Dahl, Gordon B. and Enrico Moretti. 2004. The Demand for Sons: Evidence from Divorce, Fertility, and Shotgun Marriage. National Bureau of Economic Research Working Paper 10281. Available at: http://www.nber.org/papers/w10281.

Endersby, James W. and Michael C. Munger. 1992. The impact of legislator attributes on union PAC campaign contributions. Journal of Labor Research 13(1): 79-97.

Evans, Diana. 1988. Oil PACs and Aggressive Contribution Strategies. Journal of Politics 50(4): 1047-1056.

Fleisher, Richard. 1993. PAC Contributions and Congressional Voting on National Defense. Legislative Studies Quarterly 18(3): 391- 409.

Grenzke, Janet. 1989a. Candidate Attributes and PAC Contributions. Western Political Quarterly 42(2): 245-264.

Grenzke, Janet. 1989b. PACs and the Congressional Supermarket: The Currency is Complex. American Journal of Political Science 33(1): 1-24.

Grier, Kevin B. and Michael C. Munger. 1991. Committee Assignments, Constituent Preferences, and Campaign Contributions. Economic Inquiry 29(1): 24-43. 
Grier, Kevin B. and Michael C. Munger. 1993. Comparing Interest Group PAC

Contributions to House and Senate Incumbents, 1980-1986. The Journal of Politics 55(3): 615-643.

Heckman, James J. and Thomas Macurdy. 1985. A Simultaneous Equations Linear Probability Model. The Canadian Journal of Economics. 18:28-37.

Kroszner, Randall S. and Thomas Stratmann. 2000. Does Political Ambiguity Pay? Corporate Campaign Contributions and the Rewards to Legislator Reputation. National Bureau of Economic Research Working Paper 7475. Available at: http://www.nber.org/papers/w7475.

Rudolph, Thomas J. 1999. Corporate and Labor PAC Contributions in House Elections: Measuring the Effect of Majority Party Status. The Journal of Politics 61(1): 195-206.

Stratmann, Thomas. 1991. What Do Campaign Contributions Buy? Deciphering Causal Effects of Money and Votes. Southern Economic Journal 57(3): 606-620.

Stratmann, Thomas. 1996. How Reelection Constituencies Matter: Evidence from Political Action Committees' Contributions and Congressional Voting. Journal of Law and Economics 39(2): 603-635.

Victor, Jennifer Nicoll. 2001. The Challenges of Evaluating Interest Group Influence in Congress: A Study of the $106^{\text {th }}$ House Resources Committee. Paper presented at the 2001 Midwest Political Science Association Annual Meeting, Chicago, IL.

Witko, Christopher. 2006. PACs, Issue Context, and Congressional Decisionmaking. Political Research Quarterly 59(2): 283-295. 
Figure 1: Source of Political Contributions in House Election Cycles, 2004 to Present

Source of Political Contributions in the 2008 House Election, as of October 31st, 2007

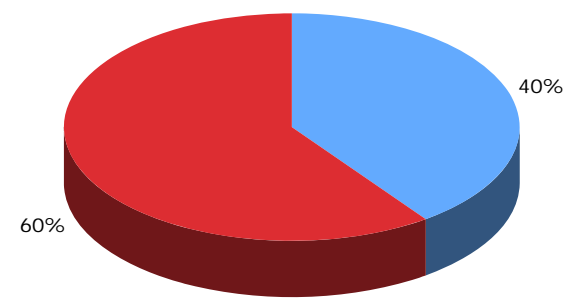

Contributions from Political Action Committees Other Contributions

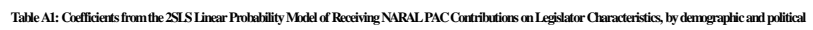

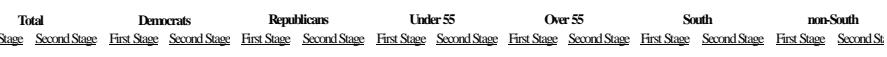

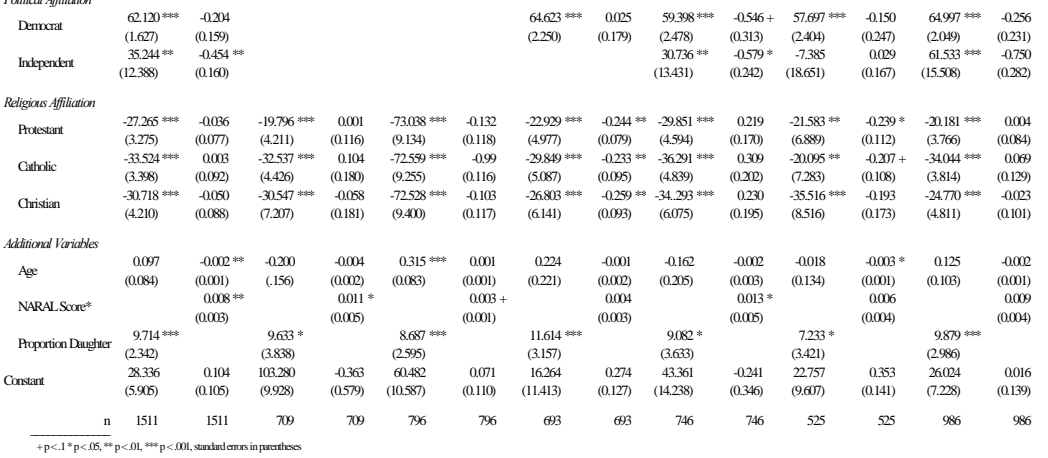

Source of Political Contributions in the 2004 House Election, January 1st, 2003 to December 31st, 2004

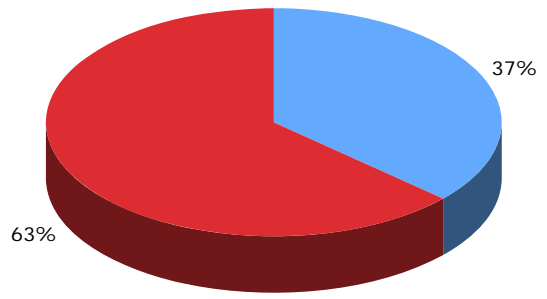

Contributions from Political Action Committees $\square$ Other Contributions

Source: Federal Election Commission (FEC) and www.opensecrets.org 
Figure 2: Average House Winner's Receipt for Political Action Committees, 19982006

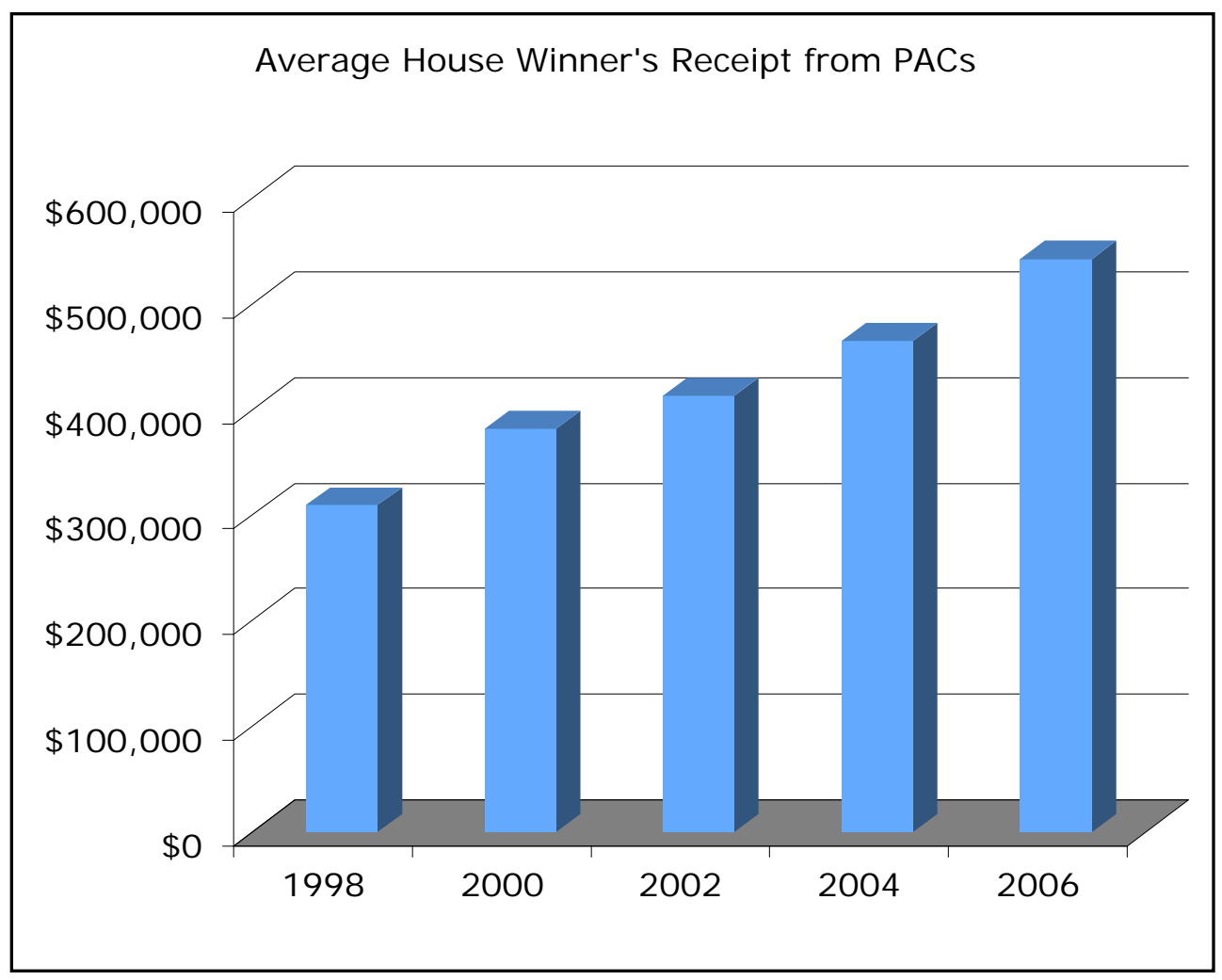

Source: www.opensecrets.org 
Figure 3: Growth of Political Action Committees, 1975 to 1999

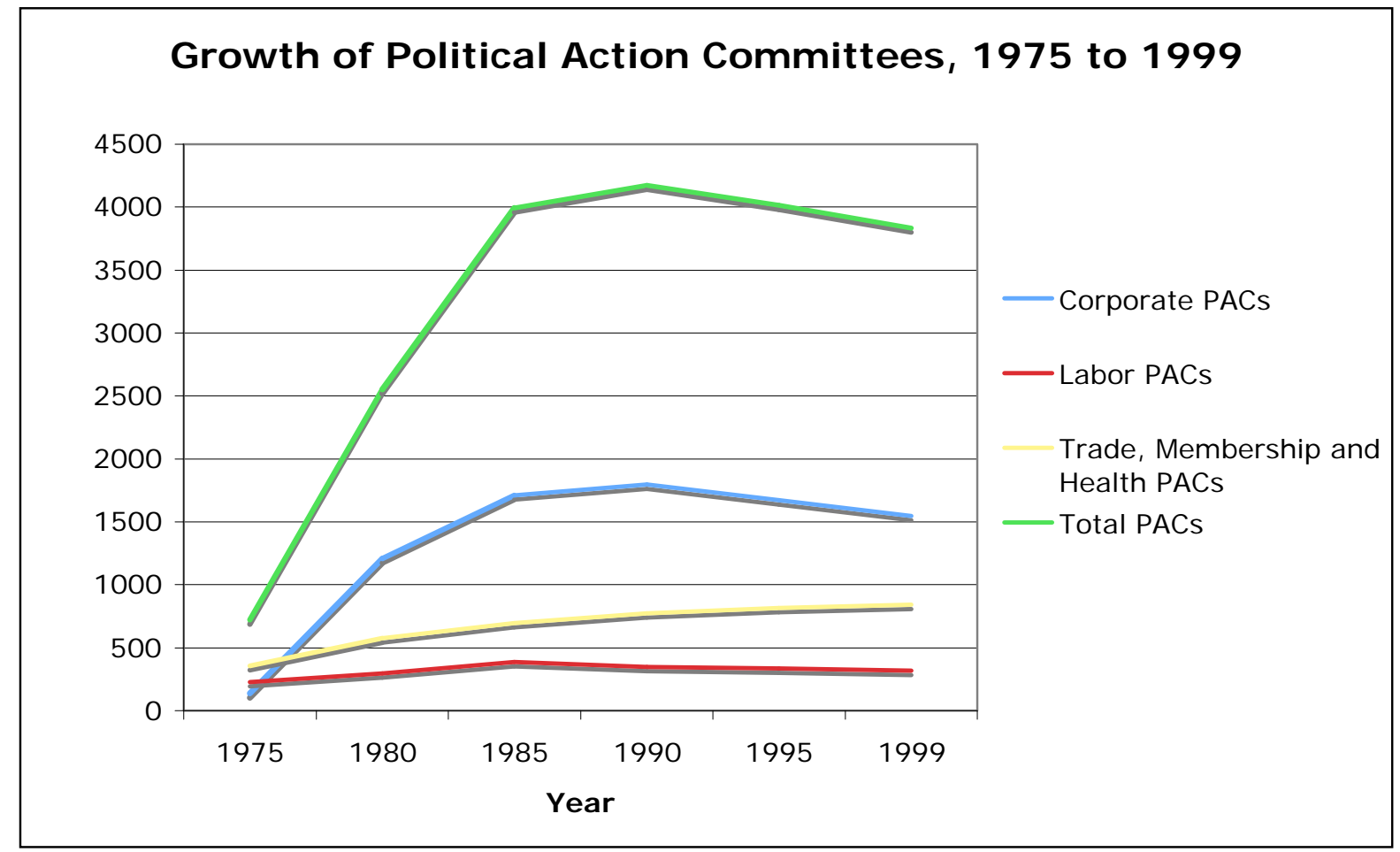

Source: Federal Election Commission, PAC Count - 1974 to Present http://www.fec.gov/press/pacchart.htm 
Figure 4: Comparison of "Naïve” OLS Parameter Estimate with IV-Regression Result

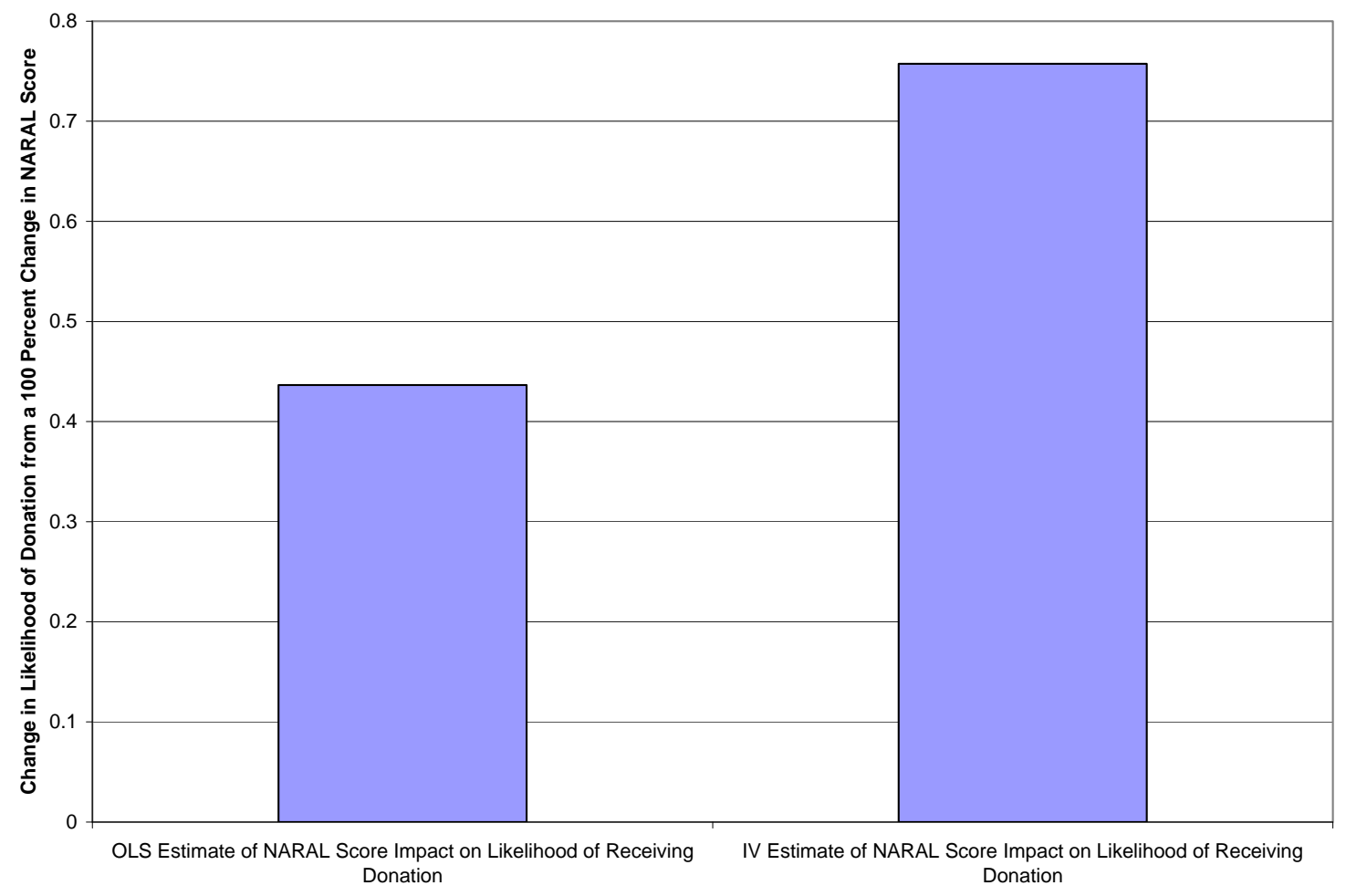


Table 1: Correlation Matrix for NARAL PAC Contributions, NARAL Scores and Legislator Characteristics

\begin{tabular}{|c|c|c|c|c|c|c|c|c|}
\hline & NARAL Score & Democrat & $\underline{\text { Independent }}$ & $\underline{\text { Age }}$ & $\underline{\text { Protestant }}$ & $\underline{\text { Catholic }}$ & $\underline{\text { Christian }}$ & $\underline{\text { Contributions }}$ \\
\hline NARAL Score & 1.000 & & & & & & & \\
\hline Democrat & 0.721 & 1.000 & & & & & & \\
\hline Independent & 0.032 & -0.056 & 1.000 & & & & & \\
\hline Age & 0.079 & 0.073 & 0.026 & 1.000 & & & & \\
\hline Protestant & -0.131 & -0.193 & -0.027 & 0.047 & 1.000 & & & \\
\hline Catholic & 0.014 & 0.145 & -0.038 & -0.086 & -0.721 & 1.000 & & \\
\hline Christian & -0.105 & -0.118 & -0.017 & 0.021 & -0.331 & -0.186 & 1.000 & \\
\hline NARAL Contribution & 0.381 & 0.264 & -0.017 & -0.009 & -0.070 & 0.007 & -0.033 & 1.000 \\
\hline
\end{tabular}


Table 2: PAC Contribution to Winning House Candidate, 1998-2006

\begin{tabular}{rrr}
$\underline{\text { Year }}$ & $\begin{array}{r}\text { Average Contribution to } \\
\text { Winning House Candidate }\end{array}$ & $\begin{array}{r}\text { Largest PAC Receipts for } \\
\text { Winning House Candidate }\end{array}$ \\
\cline { 2 - 3 } 2098 & $\$ 309,130$ & $\$ 1,163,544$ \\
2002 & $\$ 381,891$ & $\$ 1,316,733$ \\
2004 & $\$ 413,140$ & $\$ 1,743,146$ \\
2006 & $\$ 464,982$ & $\$ 1,911,381$ \\
& $\$ 542,397$ & $\$ 2,437,580$
\end{tabular}

Source: www.opensecrets.org 
Table 3: Number of Political Action Committees, 1975 to 1999

\begin{tabular}{lr} 
Year & $\begin{array}{r}\text { Number of Political } \\
\text { Action Committees }\end{array}$ \\
\hline 1974 & 608 \\
1975 & 722 \\
1976 & 1146 \\
1977 & 1360 \\
1978 & 1653 \\
1979 & 2000 \\
1980 & 2551 \\
1981 & 2901 \\
1982 & 3371 \\
1983 & 3525 \\
1984 & 4009 \\
1985 & 3992 \\
1986 & 4157 \\
1987 & 4165 \\
1988 & 4268 \\
1989 & 4178 \\
1990 & 4172 \\
1991 & 4094 \\
1992 & 4195 \\
1993 & 4210 \\
1994 & 3954 \\
1995 & 4016 \\
1996 & 4079 \\
1997 & 3844 \\
1998 & 3798 \\
1999 & 3835 \\
\hline & \\
\hline & \\
199
\end{tabular}

Source:Federal Election Commission, PAC Count Š 1974 to Present http://www.fec.gov/press/pacchart.htm 
Table 4: Results from a 2000 Fox News/Opinion Dynamics poll on Problems for the Political System.

Q: We'd like your opinion about some possible problems that might keep this country's political system from working as well as it should. Is this a major problem for this country's political system today, somewhat of a problem, or is it not much of a problem?

\section{Major Somewhat of a}

Problem for Political System

\section{Not a Problem}

Good People being

discouraged from

running for office by the

high costs of campaigns

Political Contributions

having too much

influence on elections

and government policy

Source: Newsweek Poll, conducted 1/6-7/00. 753 adults surveyed; compiled by the CitizenÕs Research Foundation for the Study of Campaign Finance Reform at the University of California at Berkeley 
Table 5: 2000 Newsweek Poll on Influence in Washington

Do you think [see below] have/has too much or too little power and influence on Washington?

\begin{tabular}{|c|c|c|c|c|}
\hline Influential Parties & Too much & Too little & $\begin{array}{r}\text { About right } \\
\text { (volunteered) }\end{array}$ & Don't Know \\
\hline Big Companies & $84 \%$ & $6 \%$ & $4 \%$ & $5 \%$ \\
\hline \multicolumn{5}{|c|}{ Political Action Committees, which give } \\
\hline money to candidates & $83 \%$ & $7 \%$ & $2 \%$ & $9 \%$ \\
\hline News Media & $77 \%$ & $8 \%$ & $8 \%$ & $7 \%$ \\
\hline Political Lobbyists & $74 \%$ & $12 \%$ & $4 \%$ & $10 \%$ \\
\hline TVŹand Radio Talk Shows & $54 \%$ & $24 \%$ & $10 \%$ & $12 \%$ \\
\hline Labor Unions & $39 \%$ & $40 \%$ & $7 \%$ & $15 \%$ \\
\hline Opinion Polls & $35 \%$ & $44 \%$ & $8 \%$ & $13 \%$ \\
\hline Racial Minorities & $32 \%$ & $50 \%$ & $8 \%$ & $10 \%$ \\
\hline Churches and Religious Groups & $27 \%$ & $52 \%$ & $9 \%$ & $12 \%$ \\
\hline Public Opinion & $15 \%$ & $74 \%$ & $6 \%$ & $5 \%$ \\
\hline Small Business & $5 \%$ & $85 \%$ & $3 \%$ & $6 \%$ \\
\hline
\end{tabular}

Source: Fox News/Opinion Dynamics poll, conducted 5/10-11/2000. 900 Registered Voters surveyed; Compiled by the CitizenÕs Research Foundation for the Study of Campaign Finance Reform at the University of California at Berkeley 
Table 6: NARAL Scores for Legislators, by Congress

\begin{tabular}{|c|c|c|c|c|c|c|c|c|}
\hline & \multicolumn{2}{|c|}{ 105th Congress } & \multicolumn{2}{|c|}{ 106th Congress } & \multicolumn{2}{|c|}{ 107th Congress } & \multicolumn{2}{|c|}{ 108th Congress } \\
\hline & $\begin{array}{c}\text { No. of } \\
\text { Legislators } \\
\end{array}$ & $\begin{array}{c}\text { Percentage of } \\
\text { Total Legislators } \\
\end{array}$ & $\begin{array}{c}\text { No. of } \\
\text { Legislators } \\
\end{array}$ & $\begin{array}{c}\text { Percentage of } \\
\text { Total Legislators }\end{array}$ & $\begin{array}{c}\text { No. of } \\
\text { Legislators } \\
\end{array}$ & $\begin{array}{c}\text { Percentage of } \\
\text { Total Legislators }\end{array}$ & $\begin{array}{c}\text { No. of } \\
\text { Legislators } \\
\end{array}$ & $\begin{array}{c}\text { Percentage of } \\
\text { Total Legislators } \\
\end{array}$ \\
\hline$\underline{\text { Score }}$ & & & & & & & & \\
\hline 0 & 131 & $30.32 \%$ & 146 & $33.80 \%$ & 212 & $48.96 \%$ & 213 & $49.08 \%$ \\
\hline 1 to 20 & 88 & $20.37 \%$ & 66 & $15.28 \%$ & 10 & $2.31 \%$ & 17 & $3.92 \%$ \\
\hline 21 to 40 & 19 & $4.40 \%$ & 16 & $3.70 \%$ & 14 & $3.23 \%$ & 31 & $7.14 \%$ \\
\hline 41 to 60 & 29 & $6.71 \%$ & 23 & $5.32 \%$ & 21 & $4.85 \%$ & 1 & $0.23 \%$ \\
\hline 61 to 80 & 24 & $5.56 \%$ & 28 & $6.48 \%$ & 17 & $3.93 \%$ & 28 & $6.45 \%$ \\
\hline 81 to 99 & 26 & $6.02 \%$ & 23 & $5.32 \%$ & 21 & $4.85 \%$ & 1 & $0.23 \%$ \\
\hline 100 & 115 & $26.62 \%$ & 130 & $30.09 \%$ & 138 & $31.87 \%$ & 143 & $32.95 \%$ \\
\hline
\end{tabular}

Source: NARAL Congressional Records on Choice, 1997-2006 
Table 7: NARAL PAC Contributions, 1998-2006

$\begin{array}{rrr}\begin{array}{r}\text { Amount of } \\ \text { Contribution }\end{array} & \begin{array}{r}\text { No. of } \\ \text { Contributions }\end{array} & \begin{array}{r}\text { Percentage of } \\ \text { Total Contributions }\end{array} \\ \$ 0 & 1,457 & 83.74 \% \\ \$ 1 \text { to } \$ 1,000 & 114 & 6.55 \% \\ \$ 1,001 \text { to } \$ 2,000 & 71 & 4.08 \% \\ \$ 2,001 \text { to } \$ 3,000 & 33 & 1.90 \% \\ \$ 3,001 \text { to } \$ 4,000 & 12 & 0.69 \% \\ \$ 4,001 \text { to } \$ 5,000 & 20 & 1.15 \% \\ \$ 5,001 \text { to } \$ 6,000 & 5 & 0.29 \% \\ \$ 6,001 \text { to } \$ 7,000 & 5 & 0.29 \% \\ \$ 7,001 \text { to } \$ 8,000 & 7 & 0.40 \% \\ \$ 8,001 \text { to } \$ 9,000 & 3 & 0.17 \% \\ \$ 9,001 \text { to } \$ 10,000 & 13 & 0.75 \%\end{array}$

Source: www.opensecrets.org Mean: \$396.87

Standard Deviasion: \$1,341.26 
Table 8: Regression Coefficients for the "Na・ve" OLS Model and the 2SLS Model

\begin{tabular}{|c|c|c|c|}
\hline Variable & Column A & Column B & Column C \\
\hline \multicolumn{4}{|l|}{ Political Affiliation } \\
\hline Democrat & $\begin{array}{r}-0.009 \\
(0.023)\end{array}$ & $\begin{array}{l}62.120 \text { *** } \\
(1.627)\end{array}$ & $\begin{array}{r}-0.204 \\
(0.159)\end{array}$ \\
\hline Independent & $\begin{array}{l}-0.339 * * \\
(0.124)\end{array}$ & $\begin{array}{l}35.244 \text { ** } \\
(12.388)\end{array}$ & $\begin{array}{l}-0.454 \text { ** } \\
(0.160)\end{array}$ \\
\hline \multicolumn{4}{|l|}{ Religious Affiliation } \\
\hline Protestant & $\begin{array}{l}-0.122 * * * \\
(0.033)\end{array}$ & $\begin{array}{l}-27.265 * * * \\
(3.275)\end{array}$ & $\begin{array}{l}-0.036 \\
(0.077)\end{array}$ \\
\hline Catholic & $\begin{array}{l}-0.102 * * \\
(0.035)\end{array}$ & $\begin{array}{l}-33.524 * * * \\
(3.398)\end{array}$ & $\begin{array}{r}0.003 \\
(0.092)\end{array}$ \\
\hline Christian & $\begin{array}{l}-0.144 * * * \\
(0.043)\end{array}$ & $\begin{array}{l}-30.718 * * * \\
(4.210)\end{array}$ & $\begin{array}{l}-0.050 \\
(0.088)\end{array}$ \\
\hline \multicolumn{4}{|l|}{ Additional Variables } \\
\hline Age & $\begin{array}{l}-0.002 * \\
(0.001)\end{array}$ & $\begin{array}{r}0.097 \\
(0.084)\end{array}$ & $\begin{array}{l}-0.002 * * \\
(0.001)\end{array}$ \\
\hline NARAL Score & $\begin{array}{l}0.004 * * * \\
(0.000)\end{array}$ & & $\begin{array}{l}0.008 \text { ** } \\
(0.003)\end{array}$ \\
\hline Proportion Daughters & & $\begin{array}{l}9.714 \text { *** } \\
(2.342)\end{array}$ & \\
\hline \multirow[t]{2}{*}{ Constant } & $\begin{array}{r}0.210 \\
(0.058)\end{array}$ & $\begin{array}{l}28.336 \\
(5.905)\end{array}$ & $\begin{array}{r}0.104 \\
(0.105)\end{array}$ \\
\hline & 1511 & 1511 & 1511 \\
\hline
\end{tabular}


Table A1: Coefficients fromthe 2SL S Linear Probability Model of Receiving NARAL PAC Contributions on Legislator Characteristics, by demographic and political

\section{Total}

Democrats

Republicans

Under 55

Over 55

South

non-South

Variable

Political Affiliation

$\begin{array}{lcc} & 62.120^{* * *} & -0.204 \\ \text { Demodat } & (1.627) & (0.159) \\ \text { Independent } & 35.244^{* *} & -0.454 \\ & (12.388) & (0.160)\end{array}$

Religious Affiliation

\begin{tabular}{|c|c|c|c|c|c|c|c|c|c|c|c|c|c|c|}
\hline Protestant & $\begin{array}{l}-27.265 \text { *k* } \\
(3.275)\end{array}$ & $\begin{array}{l}-0.036 \\
(0.077)\end{array}$ & $\begin{array}{l}-19.796 \text { *1k* } \\
(4.211)\end{array}$ & $\begin{array}{r}0.001 \\
(0.116)\end{array}$ & $\begin{array}{l}-73.038 \text { *ak } \\
(9.134)\end{array}$ & $\begin{array}{r}-0.132 \\
(0.118)\end{array}$ & $\begin{array}{l}-22.929 \text { *1*k } \\
(4.977)\end{array}$ & $\begin{array}{l}-0.244 * * \\
(0.079)\end{array}$ & $\begin{array}{l}-29.851 \text { *1** } \\
(4.594)\end{array}$ & $\begin{array}{r}0.219 \\
(0.170)\end{array}$ & $\begin{array}{l}-21.583 \text { ** } \\
(6.889)\end{array}$ & $\begin{array}{l}-0.239 * \\
(0.112)\end{array}$ & $\begin{array}{l}-20.181 \text { *** } \\
(3.766)\end{array}$ & $\begin{array}{r}0.004 \\
(0.084)\end{array}$ \\
\hline Catholic & $\begin{array}{l}-33.524 * * \\
(3.398)\end{array}$ & $\begin{array}{r}0.003 \\
(0.092)\end{array}$ & $\begin{array}{l}-32.537 \text { *1*k } \\
(4.426)\end{array}$ & $\begin{array}{r}0.104 \\
(0.180)\end{array}$ & $\begin{array}{l}-72.559 \text { ***k } \\
(9.255)\end{array}$ & $\begin{array}{r}-0.99 \\
(0.116)\end{array}$ & $\begin{array}{l}-29.849 * * * \\
(5.087)\end{array}$ & $\begin{array}{l}-0.233 * * \\
(0.095)\end{array}$ & $\begin{array}{l}-36.291 \text { *** } \\
(4.839)\end{array}$ & $\begin{array}{r}0.309 \\
(0.202)\end{array}$ & $\begin{array}{l}-20.095 * * \\
(7.283)\end{array}$ & $\begin{array}{l}-0.207+ \\
(0.108)\end{array}$ & $\begin{array}{l}-34.044^{* * *} \\
(3.814)\end{array}$ & $\begin{array}{r}0.069 \\
(0.129)\end{array}$ \\
\hline Christian & $\begin{array}{l}-30.718 * * \\
(4.210)\end{array}$ & $\begin{array}{r}-0.050 \\
(0.088)\end{array}$ & $\begin{array}{l}-30.547 \text { *1** } \\
(7.207)\end{array}$ & $\begin{array}{r}-0.058 \\
(0.181)\end{array}$ & $\begin{array}{l}-72.528 \text { *1*k } \\
(9.400)\end{array}$ & $\begin{array}{r}-0.103 \\
(0.117)\end{array}$ & $\begin{array}{l}-26.803 \text { *** } \\
(6.141)\end{array}$ & $\begin{array}{l}-0.259 * * \\
(0.093)\end{array}$ & $\begin{array}{c}-34 . .293 \text { *** } \\
(6.075)\end{array}$ & $\begin{array}{r}0.230 \\
(0.195)\end{array}$ & $\begin{array}{l}-35.516 \text { **** } \\
(8.516)\end{array}$ & $\begin{array}{r}-0.193 \\
(0.173)\end{array}$ & $\begin{array}{l}-24.770 \text { *1*k } \\
(4.811)\end{array}$ & $\begin{array}{r}-0.023 \\
(0.101)\end{array}$ \\
\hline Variabl & & & & & & & & & & & & & & \\
\hline Age & $\begin{array}{r}0.097 \\
(0.084)\end{array}$ & $\begin{array}{l}-0.002^{* *} \\
(0.001)\end{array}$ & $\begin{array}{l}-0.200 \\
(.156)\end{array}$ & $\begin{array}{r}-0.004 \\
(0.002)\end{array}$ & $\begin{array}{l}0.315 \text { *** } \\
(0.083)\end{array}$ & $\begin{array}{r}0.001 \\
(0.001)\end{array}$ & $\begin{array}{r}0.224 \\
(0.221)\end{array}$ & $\begin{array}{r}-0.001 \\
(0.002)\end{array}$ & $\begin{array}{r}-0.162 \\
(0.205)\end{array}$ & $\begin{array}{r}-0.002 \\
(0.003)\end{array}$ & $\begin{array}{r}-0.018 \\
(0.134)\end{array}$ & $\begin{array}{l}-0.003 * \\
(0.001)\end{array}$ & $\begin{array}{r}0.125 \\
(0.103)\end{array}$ & $\begin{array}{r}-0.002 \\
(0.001)\end{array}$ \\
\hline NARAL Score* & & $\begin{array}{l}0.008^{* *} \\
(0.003)\end{array}$ & & $\begin{array}{l}0.011 * \\
(0.005)\end{array}$ & & $\begin{array}{l}0.003+ \\
(0.001)\end{array}$ & & $\begin{array}{r}0.004 \\
(0.003)\end{array}$ & & $\begin{array}{c}0.013 * \\
(0.005)\end{array}$ & & $\begin{array}{r}0.006 \\
(0.004)\end{array}$ & & $\begin{array}{r}0.009 \\
(0.004)\end{array}$ \\
\hline Proportion Daughter & $\begin{array}{l}9.714^{* * *} \\
(2.342)\end{array}$ & & $\begin{array}{c}9.633 * \\
(3.838)\end{array}$ & & $\begin{array}{l}8.687 \text { *** } \\
(2.595)\end{array}$ & & $\begin{array}{l}11.614 \text { *** } \\
(3.157)\end{array}$ & & $\begin{array}{l}9.082 * \\
(3.633)\end{array}$ & & $\begin{array}{c}7.233 * \\
(3.421)\end{array}$ & & $\begin{array}{l}9.879 \text { *** } \\
(2.986)\end{array}$ & \\
\hline tant & $\begin{array}{l}28.336 \\
(5.905)\end{array}$ & $\begin{array}{r}0.104 \\
(0.105)\end{array}$ & $\begin{array}{c}103.280 \\
(9.928)\end{array}$ & $\begin{array}{r}-0.363 \\
(0.579)\end{array}$ & $\begin{array}{r}60.482 \\
(10.587)\end{array}$ & $\begin{array}{r}0.071 \\
(0.110)\end{array}$ & $\begin{array}{r}16.264 \\
(11.413)\end{array}$ & $\begin{array}{r}0.274 \\
(0.127)\end{array}$ & $\begin{array}{r}43.361 \\
(14.238)\end{array}$ & $\begin{array}{r}-0.241 \\
(0.346)\end{array}$ & $\begin{array}{l}22.757 \\
(9.607)\end{array}$ & $\begin{array}{r}0.353 \\
(0.141)\end{array}$ & $\begin{array}{l}26.024 \\
(7.228)\end{array}$ & $\begin{array}{r}0.016 \\
(0.139)\end{array}$ \\
\hline $\mathrm{n}$ & 1511 & 1511 & 709 & 709 & 796 & 796 & 693 & 693 & 746 & 746 & 525 & 525 & 986 & \\
\hline
\end{tabular}

$\begin{array}{lrllllll}64.623^{* * *} & 0.025 & 59.398 \text { *** } & -0.546+ & 57.697 \text { *** } & -0.150 & 64.997 \text { *** } & -0.256 \\ (2.250) & (0.179) & (2.478) & (0.313) & (2404) & (0.247) & (2.049) & (0.231) \\ & & 30.736 * * & -0.579 * & -7.385 & 0.029 & 61.533 * * * & -0.750 \\ & & (13.431) & (0.242) & (18.651) & (0.167) & (15.508) & (0.282)\end{array}$

$\begin{array}{llllll}(13.431) & (0.242) & (18.651) & (0.167) & (15.508) & (0.282)\end{array}$

${ }^{+} \mathrm{p}<.1 * \mathrm{p}<.05, * * \mathrm{p}<.01,{ }^{* * *} \mathrm{p}<.001$, standard enors in parentheses 